\title{
Synthesis and Radiosynthesis of Prospective 2-Nitroimidazole Hypoxia PET Tracers via Thiazolidine Ligation with 5-Fluorodeoxy- ribose (FDR)
}

\author{
M. Musolino ${ }^{a}$ \\ S. Dall'Angelo*a (D) \\ M. Zanda*a,b \\ a Institute of Medical Sciences and Kosterlitz Centre for Thera- \\ peutics, School of Medicine, Medical Sciences and Nutrition, \\ University of Aberdeen, Foresterhill, Aberdeen, AB25 2ZD, \\ Scotland, UK \\ m.zanda@abdn.ac.uk \\ s.dallangelo@abdn.ac.uk

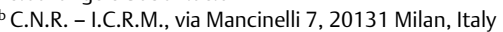
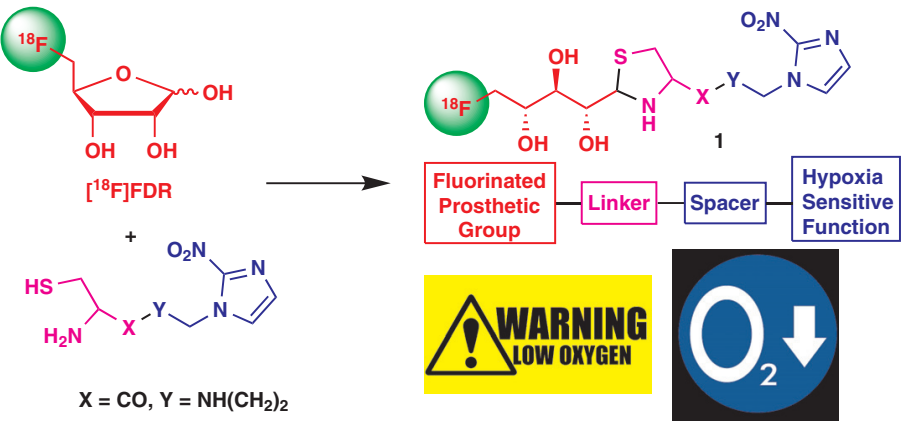

Received: 19.10 .2017

Accepted: 21.11.2017

Published online: 12.12 .2017

DOI: 10.1055/s-0036-1591863; Art ID: so-2017-d0048-I

License terms: cc)

Abstract The first prospective fluorinated PET tracers for imaging hypoxia obtained via thiazolidine-ligation are reported. Three 1,2-thiolamine linkers were combined with four different 2-nitroimidazole spacers via amide or urea bond formation. The resulting compounds were submitted to thiazolidine-ring-forming ligation reaction with the fluorinated carbohydrate L-5-fluoro-5-deoxy-ribose (FDR), affording the desired candidate PET tracers in variable yields. The same ligation reactions performed on L-ribose - a by-product of [ $\left.{ }^{18} \mathrm{~F}\right] \mathrm{FDR}$ radiosynthesis under conditions mimicking a radiochemical production showed that the fluorinated adducts can be efficiently purified and isolated by HPLC. Finally, one of the prospective hypoxia tracers was successfully produced in radiolabelled form in $29.2 \%$ radiochemical yield from $\left[{ }^{18} \mathrm{~F}\right] \mathrm{FDR}$.

Key words hypoxia, radiofluorination, thiazolidines, nitroimidazole, bio-orthogonal ligation

Hypoxia occurs in cells and tissues when oxygen demand exceeds supply. ${ }^{1,2}$ The irregular vasculature typical of solid tumours does not sufficiently support cellular oxygen demand, leading to the development and progression of heterogeneous hypoxic cancer areas, which are generally poorly responsive to chemo- and radio-therapies. ${ }^{3,4}$ Accurate imaging of hypoxic regions could allow clinicians to stratify patients and develop more efficient treatment strategies to improve therapeutic outcomes. ${ }^{5,6}$ Identification and quantification of hypoxic areas in tumours - and in other pathologies - is therefore important for planning the most appropriate and personalised therapeutic approach., 7,8 Owing to its high sensitivity and non-invasive nature, PET imaging is emerging as the method of choice for in vivo identification, characterization and discrimination of hypoxic areas. ${ }^{6,9}$ In the last two decades, several PET tracers for hypoxia have been described, but all of them are affected by significant drawbacks, such as low signal-to-noise ratios, slow accumulation in hypoxic regions and poor brain uptake, therefore the development of new hypoxia-targeted PET tracers remains a very active area of research. ${ }^{10,11} \mathrm{~L}-5$ Fluoro-5-deoxy-ribose ( $\left.\left[{ }^{18} \mathrm{~F}\right] \mathrm{FDR}\right) \mathbf{2}$ (Figure 1 ) has recently emerged as a promising prosthetic group for rapid, indirect radiolabelling of bioactive molecules via oxime bond formation. ${ }^{12-15}$

As an alternative to the oxime bond, thiazolidine ring formation could be used as a site-specific ligation method via reaction of a 1,2-thiol-amine function with a carbonyl group - including masked carbonyls of carbohydrates and hemiacetals - in mildly acidic or basic conditions ( $\mathrm{pH} 4$ to 8). ${ }^{16-18}$ Importantly, the thiazolidine ring is generally stable in a wide $\mathrm{pH}$ range (from 4 to 10 ), thus representing an attractive linkage option. In order to further investigate the efficiency of $\left[{ }^{18} \mathrm{~F}\right] \mathrm{FDR}$ as a radiolabelling agent and expand the library of prospective PET tracers for hypoxia imaging, we designed a novel class of candidate tracers $\left[{ }^{18} \mathrm{~F}\right] \mathbf{1}$ (Figure 1) taking advantage of the last-step formation of a thiazolidine ring linkage between $\left[{ }^{18} \mathrm{~F}\right]$ FDR 2 and terminal 2-amino-thiols 3 carrying a hypoxia-reactive 2-nitroimidazole group.

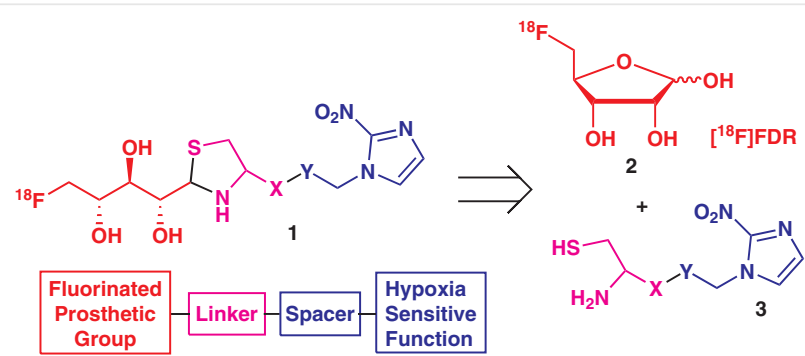

Figure 1 Novel hypoxia PET tracers via thiazolidine ligation with $\left[{ }^{18} \mathrm{~F}\right] \mathrm{FDR}$ 
Three different 2-aminoethanethiol linkers 4a-c (Scheme 1) were selected to modulate the steric constraints and lipophilicity of the final candidate tracers. The synthesis was based on the conditions described by Duthaler et al. ${ }^{19}$ A mixture of racemic cysteine $\mathbf{5}$ and conc. $\mathrm{HCl}$ in acetone was heated at reflux for $6 \mathrm{~h}$, affording the thiazolidine intermediate $\mathbf{6}$. Samples of $\mathbf{6}$ were invariably found (by ${ }^{1} \mathrm{H}$ NMR spectroscopy) to contain $5-10 \%$ of cysteine hydrochloride 7. The mixture of $\mathbf{6}$ and $\mathbf{7}$ was allowed to react with (Boc) $)_{2} \mathrm{O}$ in pyridine for 3 days to give the $\mathrm{N}$-Boc-derivative 4a. ${ }^{19}$ NMR spectroscopy showed that this compound exists as a mixture of rotamers, the signals of which did not show coalescence at $60{ }^{\circ} \mathrm{C}$ either in $\mathrm{CDCl}_{3}$ or in $\mathrm{CD}_{3} \mathrm{OD}$. Compound 4a was converted into the Weinreb amide $\mathbf{8}$ by reaction with HATU and DIPEA, followed by addition of $\mathrm{N}, \mathrm{O}$-dimethylhydroxylamine hydrochloride. Reduction of 8 using $\mathrm{LiAlH}_{4}$ at $0{ }^{\circ} \mathrm{C}$ provided in good yield the aldehyde $\mathbf{9}$, which was submitted to Wittig reaction with the phosphonium ylide $\mathrm{Ph}_{3} \mathrm{P}=\mathrm{CHCO}_{2} \mathrm{Me}$ to give exclusively the trans isomer of the $\alpha, \beta$-unsaturated ester $10{ }^{20}$ Hydrogenation reaction of 10 using $\mathrm{H}_{2}$ over $\mathrm{Pd} / \mathrm{C}$ catalyst gave in quantitative yield the saturated intermediate 11, which afforded the free carboxylic acid $\mathbf{4} \mathbf{b}^{21}$ by basic hydrolysis of the ester function. The carbinol 12 was obtained upon treatment of 11 with $\mathrm{LiAlH}_{4}$ at $0{ }^{\circ} \mathrm{C}$, whereas the amine derivative $4 \mathbf{c}^{22}$ was obtained via
Mitsunobu reaction of phthalimide with 12 to give compound 13, followed by phthalimide-ring cleavage with hydrazine monohydrate.

The 2-nitro-imidazole spacers 14a-d (Scheme 2 and Scheme 3) were selected with the aim of introducing structural diversity within the series. The structure of the spacer was expected to have an important effect on lipophilicity, metabolic stability and ultimately on the imaging potential of the candidate tracers 1 .

Amines 14a,b were synthesised via Gabriel reaction (Scheme 2) starting respectively from commercial 1,3-dibromopropane (15a) and 1,5-dibromopentane (15b). The resulting phthalimides $\mathbf{1 6 a}, \mathbf{b}^{23}$ were reacted with 2-nitroimidazole and $\mathrm{K}_{2} \mathrm{CO}_{3}$ in DMF upon heating to $115^{\circ} \mathrm{C}$ to give compounds $\mathbf{1 7} \mathbf{a}, \mathbf{b}^{24}$ in good yields. The desired amines 14a,b were obtained by quantitative cleavage of the phthalimido group with hydrazine monohydrate. The 1,2,3triazole-amine 14c was prepared via Huisgen cycloaddition reaction between the azide $\mathbf{1 8}$, which was obtained by bromine displacement reaction of $\mathbf{1 6} \mathbf{a}$ with sodium azide, ${ }^{25}$ and 1-propargyl-2-nitroimidazole 19, which was prepared according to the literature, ${ }^{26}$ to afford phthalimide derivative 20. Removal of the phthalimido group with hydrazine gave compound 14c in good overall yield.
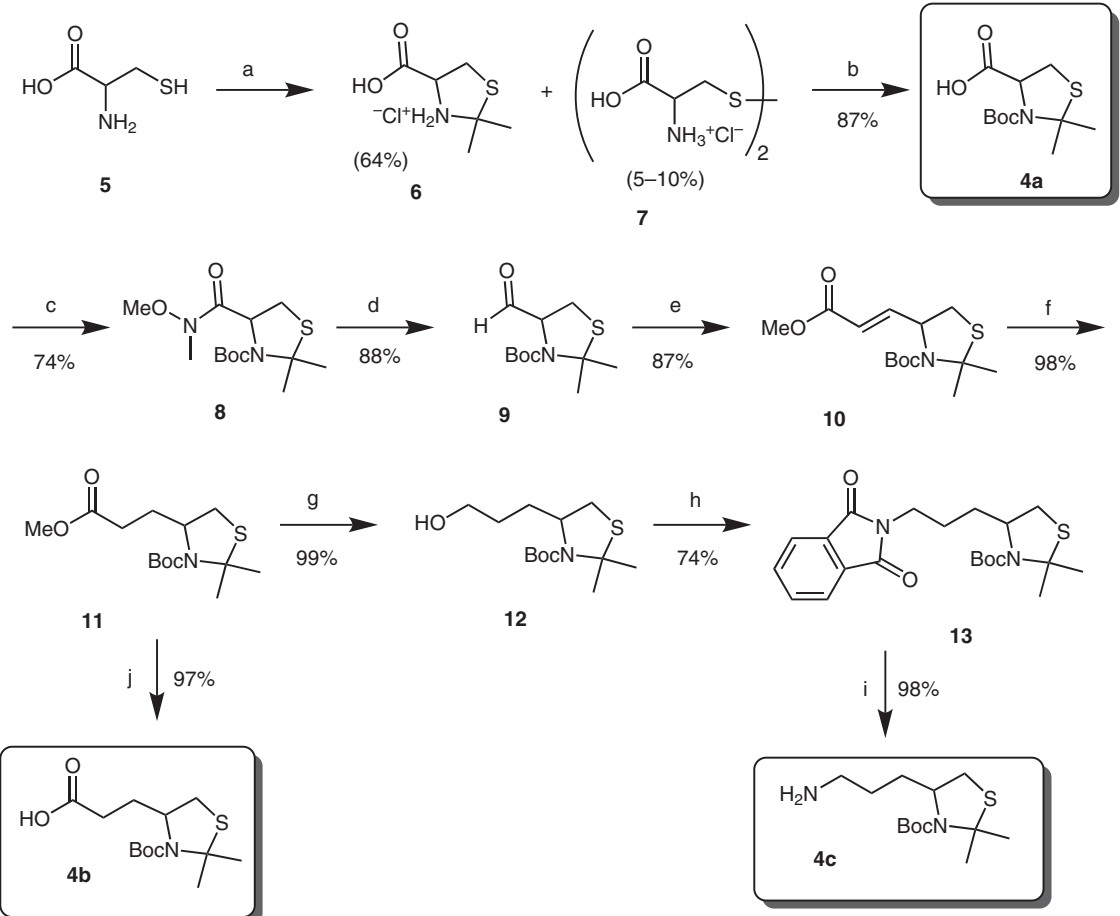

$+\frac{10}{20}$
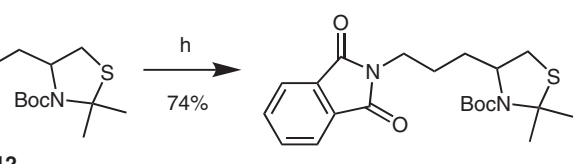

12

13

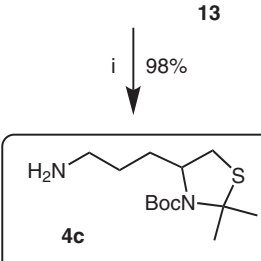

Scheme 1 Synthesis of thiazolidine linkers $4 a-c$. Reagents and conditions: (a) acetone, conc. $\mathrm{HCl}$, reflux, 6 h; (b) Boc $2 \mathrm{O}$, pyridine, $\mathrm{N}_{2}$ atm., r.t., 72 h; (c) $\mathrm{N}, \mathrm{O}$-Dimethylhydroxylamine hydrochloride, DIPEA, $\mathrm{CH}_{2} \mathrm{Cl}_{2}, \mathrm{HATU}$, from $0{ }^{\circ} \mathrm{C}$ to r.t., $18 \mathrm{~h}$; (d) $\mathrm{LiAlH}_{4}, \mathrm{Et}_{2} \mathrm{O}, \mathrm{N}_{2}$ atm., $0{ }^{\circ} \mathrm{C}, 15 \mathrm{~min} ;(\mathrm{e}) \mathrm{Ph}_{3} \mathrm{P}=\mathrm{CHCO} \mathrm{Me} \mathrm{THF}$,

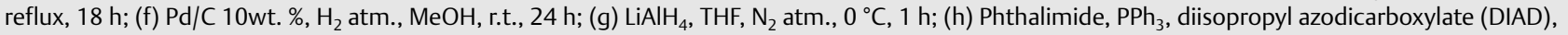
THF, r.t., 16 h; (i) $\mathrm{NH}_{2} \mathrm{NH}_{2} \cdot \mathrm{H}_{2} \mathrm{O}$, reflux, 3 h; (j) LiOH, THF, r.t., 18 h. 


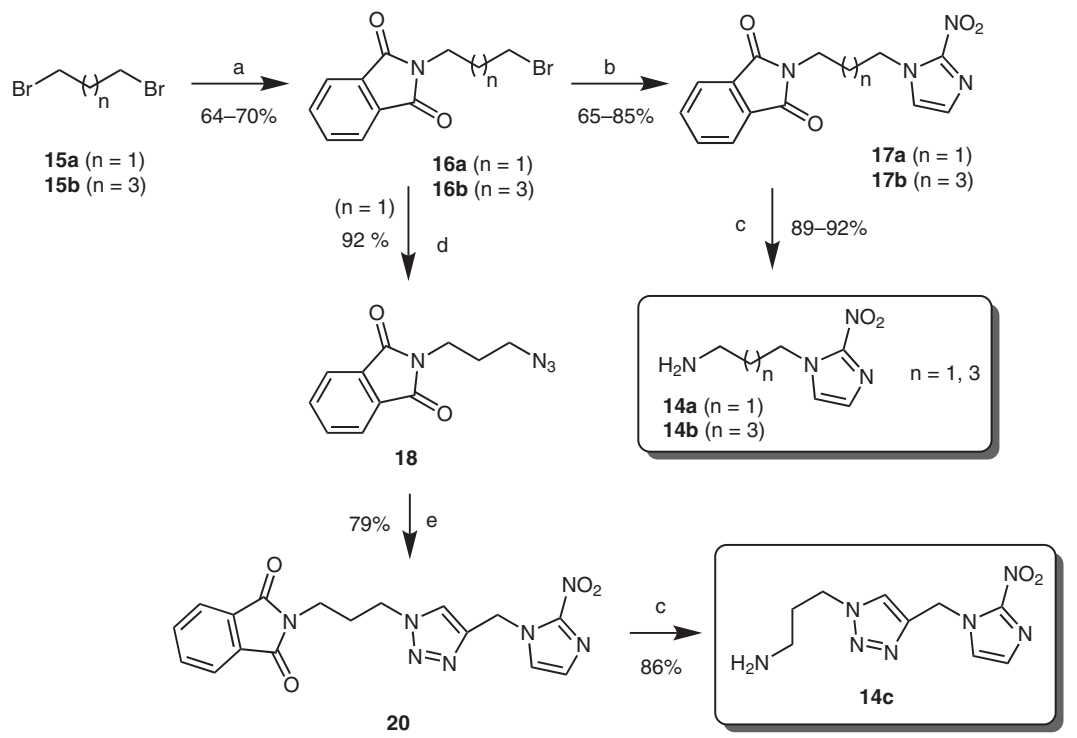

Scheme 2 Synthesis of 2-nitroimidazole spacers 14a-c. Reagents and conditions: (a) Phthalimide, TEA, DMF, r.t., 48 h; (b) 2-Nitroimidazole, $\mathrm{K}_{2} \mathrm{CO}_{3}$, DMF, 110-120 ${ }^{\circ} \mathrm{C}, 3-5 \mathrm{~h}$; (c) $\mathrm{NH}_{2} \mathrm{NH}_{2} \cdot \mathrm{H}_{2} \mathrm{O}, \mathrm{EtOH}, 60-100{ }^{\circ} \mathrm{C}, 1-4 \mathrm{~h}$; (d) $\mathrm{NaN}_{3}$, DMF, $120^{\circ} \mathrm{C}, 4 \mathrm{~h}$; (e) 1-Propargyl-2-nitroimidazole 19, CuSO ${ }_{4}$, sodium ascorbate, $t-\mathrm{BuOH} / \mathrm{H}_{2} \mathrm{O}$, r.t., 20 h.

2-Nitro-imidazolyl-acetic acid $\mathbf{1 4 d}^{27}$ (Scheme 3) was prepared in four steps starting from 21, which provided compound $\mathbf{2 2}$ after protection of the hydroxy group as tetrahydropyranyl acetal (THP) followed by introduction of the 2-nitroimidazole function in $\mathrm{K}_{2} \mathrm{CO}_{3}$ and DMF upon heating to $115^{\circ} \mathrm{C}$. The resulting intermediate $\mathbf{2 3}$ was then dissolved in a $6 \mathrm{M}$ aq. $\mathrm{HCl}$ solution in $\mathrm{MeOH}$ to cleave the THP group, followed by treatment of the resulting carbinol 24 with Jones reagent $\left(\mathrm{CrO}_{3} / \mathrm{H}_{2} \mathrm{SO}_{4} /\right.$ acetone $)$ in acetone to give the desired compound 14d in $41 \%$ yield over the three steps.

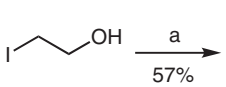

21<smiles>CCN(CC)C(=O)[O-]</smiles>

24

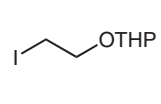

22

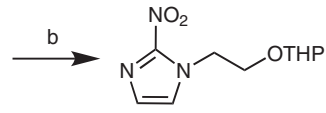

23

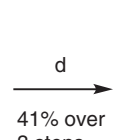

3 steps

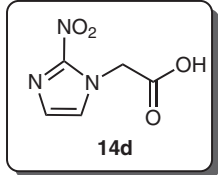

Scheme 3 Synthesis of 2-nitroimidazole spacer 14d. Reagents and conditions: (a) DHP, PPTS, $\mathrm{CH}_{2} \mathrm{Cl}_{2}$, r.t., 18 h; (b) 2-Nitroimidazole, $\mathrm{K}_{2} \mathrm{CO}_{3}$, DMF, $115^{\circ} \mathrm{C}, 5 \mathrm{~h}$; (c) $6 \mathrm{M} \mathrm{HCl}$, $\mathrm{MeOH}$, r.t., 18 h; (d) $\mathrm{CrO}_{3} / \mathrm{H}_{2} \mathrm{SO}_{4} /$ acetone, r.t., $12 \mathrm{~h}$.

Assembling of linkers $\mathbf{4 a - c}$ and spacers 14a-d to give the tracers' precursors 3a-f is shown in Scheme 4. Treatment of carboxylic acid derivatives $\mathbf{4 a - c}$ with HATU and DIPEA gave the corresponding activated esters, which were reacted in situ with the amines $\mathbf{1 4 a - d}$ to afford the amides 25a-e. ${ }^{28}$ Different conditions were used to prepare the urea derivative $\mathbf{2 5 f} .{ }^{29}$ In this case, the amine $\mathbf{4 c}$ was added drop- wise to a solution of carbonyldiimidazole (CDI) in $\mathrm{CH}_{2} \mathrm{Cl}_{2}$ at $0{ }^{\circ} \mathrm{C}$ to give the intermediate imidazocarboxyamide, which gave the desired urea $\mathbf{2 5 f}$ upon in situ treatment with the amine 14a.

The final unprotected 2-aminoethanethiol derivatives 3a- $\mathbf{f}^{30}$ (Scheme 4) were obtained by treatment of $\mathbf{2 5 a}-\mathbf{f}$ with a TFA $/ \mathrm{H}_{2} \mathrm{O} / \mathrm{MeOH} 3: 2: 1$ mixture upon heating to $65^{\circ} \mathrm{C}$ for $2-4 \mathrm{~h}$, followed by solvents removal under reduced pressure at $60{ }^{\circ} \mathrm{C}$. Then the crude compounds were dissolved in ethanol (except compound 3c, which is only soluble in aqueous solutions) and eluted through a SiliaBond ${ }^{\circledR}$ carbonate pad (silica bound equivalent of tetramethylammonium carbonate), which trapped residual TFA, acid by-products and free-based 2-nitroimidazolium trifluoroacetate salts formed during the thiazolidine hydrolysis.

In all cases, variable amounts of disulphide dimers were obtained in mixture with the desired thiol monomers 3a-f, as evidenced by both HPLC/MS analysis and NMR spectroscopy. However, we did not attempt to purify further the samples, as the disulphide dimers could be readily reduced back to the monomeric thiols by treatment with 1,4-dithiothreitol (DTT) before the following ligation reaction with FDR 2 (Scheme 5).

The thiazolidine ring formation was performed by reaction of 3a-f with cold $\left[{ }^{19} \mathrm{~F}\right]$ FDR 2 using $1 \mathrm{M}$ acetate buffer as reaction medium in the presence of DTT. Acetate buffers with different molarity (from 0.1 to 4.0 ) and $\mathrm{pH}$ (from 3 to 6) were tested at different temperatures (from r.t. to $50^{\circ} \mathrm{C}$ ) in order to optimise the thiazolidine ring formation rate. The optimised conditions were 2.5 equiv of $\mathbf{3 a}-\mathbf{f}$ reacted with 1 equiv of $\left[{ }^{19} \mathrm{~F}\right] \mathrm{FDR}(\mathbf{2})$ in the presence of 2.5 equiv of DTT, using $1 \mathrm{M}$ acetate buffer at $\mathrm{pH} 4.5$ as reaction medium, 

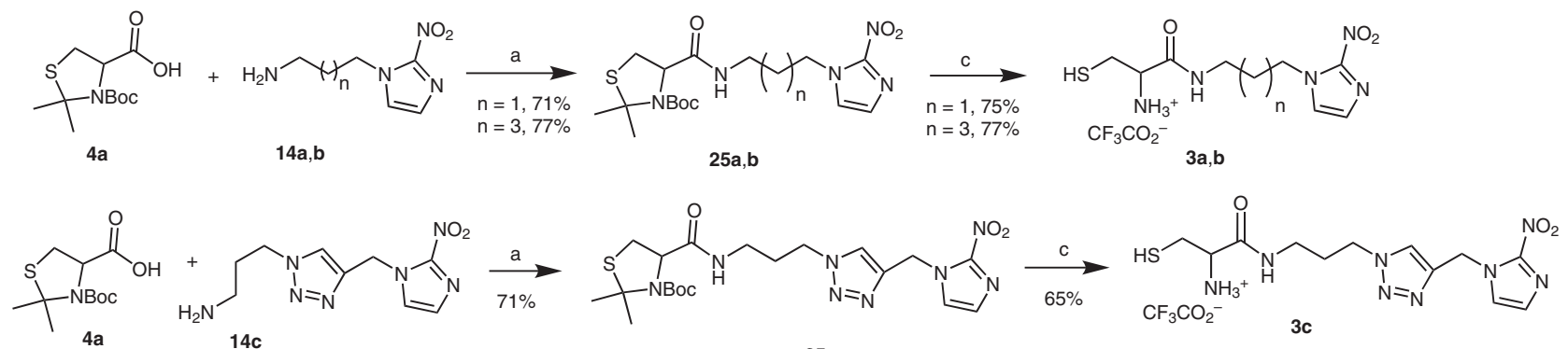

$25 c$

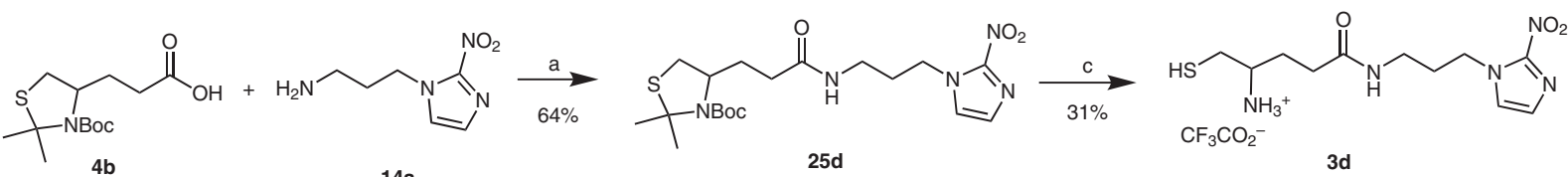

$14 a$

$25 d$

3d

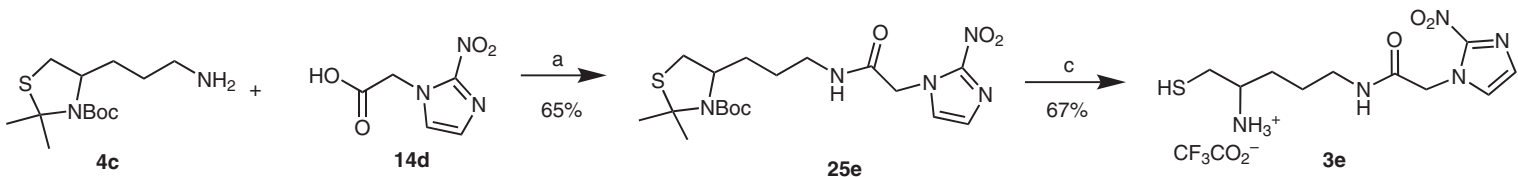
14d<smiles>CC(C)(C)C(C)(C)C(=O)O[N+](=O)c1nccn1CCCN</smiles>

$4 c$
$14 a$

Scheme 4 Synthesis of the 2-amino-thiol tracer precursors 3a-f. Reagents and conditions: (a) HATU, DIPEA, $\mathrm{CH}_{2} \mathrm{Cl}_{2}$, r.t., 18 h; (b) $\mathrm{CDI}_{1} \mathrm{CH}_{2} \mathrm{Cl}_{2}$, from $0{ }^{\circ} \mathrm{C}$ to r.t., $18 \mathrm{~h}$; (c) $\mathrm{TFA} / \mathrm{H}_{2} \mathrm{O} / \mathrm{MeOH}$ 3:2:1, from r.t. to $65^{\circ} \mathrm{C}, 2-4 \mathrm{~h}$.

for $20 \mathrm{~min}$ at $30^{\circ} \mathrm{C}$. The purification step was performed by gradient RP-HPLC using a mixture of $\mathrm{H}_{2} \mathrm{O} / \mathrm{ACN}+0.05 \%(\mathrm{v} / \mathrm{v})$ of TFA as eluent. 1,2-Aminothiol derivatives 3a-f showed markedly different reactivity towards [ $\left.{ }^{19} \mathrm{~F}\right]$ FDR $\mathbf{2}$, showing that the spacers' structure plays an important role in the cyclisation reaction (see Table 1 for yields). Only the 1,2-thiolamine derivative $\mathbf{3 c}$, incorporating a triazole ring, failed to react under all the conditions explored, affording in very low yields $(<5 \%)$ the corresponding thiazolidine 1c, which could not be isolated in pure form by RP-HPLC purification.

The radiosynthesis of $\left[{ }^{18} \mathrm{~F}\right]$ FDR 2 is known to produce an excess of L-ribose $\mathbf{2 6}$ as by-product, ${ }^{12}$ which, although less reactive than $\mathbf{2}$, will compete with it in the thiazolidine ring formation, affording the corresponding non-fluorinated thiazolidines 27a-f (Scheme 5) and decreasing the chemical purity of the tracer.

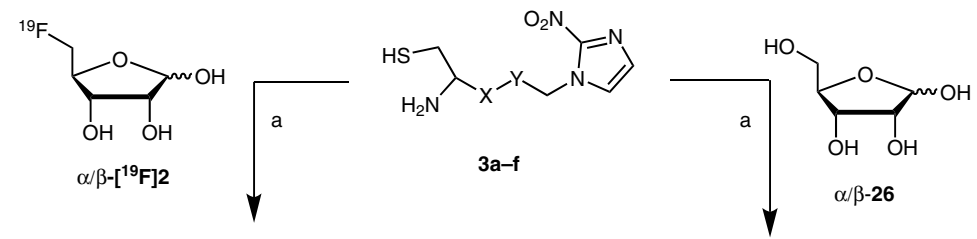<smiles>[Y]C1=NC([C@H](O)[C@H](O)[C@H](O)C[18F])SC1</smiles>

$1 a-f$<smiles>[Y]C1CSC([C@H](O)[C@H](O)[C@H](O)CO)N1</smiles>

27a-f

Scheme 5 (a) $1 \mathrm{M}$ acetate buffer $\mathrm{CH}_{3} \mathrm{COOH} / \mathrm{CH}_{3} \mathrm{COONa}$, pH 4.5, r.t., 20 min 
Table 1 Synthesis of Cold Tracers $\left[{ }^{19} \mathrm{~F}\right] \mathbf{1} \mathbf{a}-\mathbf{f}$

\begin{tabular}{|c|c|c|c|c|c|c|}
\hline Compound & $x$ & Y & Yield (\%) & $t_{R-F}(\min )$ & $t_{R-\mathrm{OH}}(\min )^{\mathrm{a}}$ & $\log P( \pm$ SED $)$ \\
\hline $1 a$ & $\mathrm{CO}$ & $\mathrm{NH}\left(\mathrm{CH}_{2}\right)_{2}$ & 61.3 & 12.5 & 8.3 & $0.33( \pm 0.04)$ \\
\hline $1 b$ & $\mathrm{CO}$ & $\mathrm{NH}\left(\mathrm{CH}_{2}\right)_{4}$ & 67.9 & $27.3,28.4$ & 20.0 & $0.64( \pm 0.04)$ \\
\hline 1d & $\left(\mathrm{CH}_{2}\right)_{2} \mathrm{CO}$ & $\mathrm{NH}\left(\mathrm{CH}_{2}\right)_{2}$ & 11.2 & $22.4-23.4$ & 20.3 & $0.68( \pm 0.04)$ \\
\hline $1 e$ & $\left(\mathrm{CH}_{2}\right)_{3} \mathrm{NH}$ & $\mathrm{CO}$ & 31.8 & $15.6-18.4$ & $10.0-11.5$ & $0.26( \pm 0.04)$ \\
\hline $1 f$ & $\left(\mathrm{CH}_{2}\right)_{3} \mathrm{NH}$ & $\mathrm{CONH}\left(\mathrm{CH}_{2}\right)_{3}$ & 42.3 & $27.7-29.4$ & $22.0-23.5$ & $0.50( \pm 0.02)$ \\
\hline
\end{tabular}

a Retention time of the corresponding L-ribose analogue $\mathbf{2 6 .}$

To simulate the radiosynthesis conditions, the thiazolidine ring formation reaction was carried out in the presence of 10 equiv of $\mathbf{2 6}$ along with 1 equiv of [ ${ }^{19}$ F]FDR $\mathbf{2}$ and 1,2-aminothiol derivatives $\mathbf{3 a}$-f. This experiment was performed with the aim of assessing the formation of the desired FDR thiazolidines in the presence of L-ribose $\mathbf{2 6}$ and the possibility of performing an HPLC purification for separating the $\left[{ }^{18} \mathrm{~F}\right]$ FDR-derived tracers $\mathbf{1 a}-\mathbf{f}$ from the non-radioactive L-ribose-derived thiazolidines 27a-f. As shown in Table 1, as well as in the HPLC profiles (see the Supporting Information), the retention times of the target FDR-thiazolidines $\mathbf{1 a}-\mathbf{f}$ are indeed significantly different to those of the ribose-derived thiazolidines $\mathbf{2 7} \mathbf{a}-\mathbf{f}$.

Therefore, the final cold tracers $\left[{ }^{19} \mathrm{~F}\right] \mathbf{1 a}-\mathbf{f}$ could be isolated and characterised by LC-MS. Their $\log P$ values were determined by RP-HPLC (isocratic phase $\mathrm{H}_{2} \mathrm{O}$ /EtOH 90:10). Considering that the gold standard hypoxia tracer $\left[{ }^{18} \mathrm{~F}\right] \mathrm{FMI}-$ SO has a $\log P=0.42$, candidate tracers 1 appear to have suitable lipophilicity for use in vivo. Thiazolidines 1a-f presented very complex NMR spectra owing to the presence of four diastereomers, originated by the two $(R / S)$ thiazolidine stereogenic centres, plus different rotamers and trifluoroacetate salts. Only compound $\mathbf{1} \mathbf{a}^{31}$ was isolated in sufficient quantity for being satisfactorily characterised by NMR spectroscopy, after treatment with SiliaBond ${ }^{\circledR}$ carbonate in order to freebase the trifluoroacetate salts.

Radiolabelling tests for producing $\left[{ }^{18} \mathrm{~F}\right] \mathbf{1} \mathbf{a}^{32}$ were conducted on the 1,2-aminothiol derivative $\mathbf{3 a}$, which was treated with $\left[{ }^{18} \mathrm{~F}\right] \mathrm{FDR}(\mathbf{2})^{12,13}$ using a sodium acetate buffer solution (Scheme 6). Also in this case, different reaction conditions were tested with the aim of achieving the maximum radiochemical conversion within 40 minutes (see Table 1S, Supporting Information).

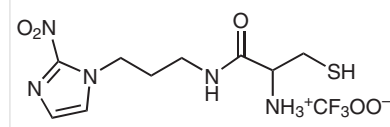

$3 a$

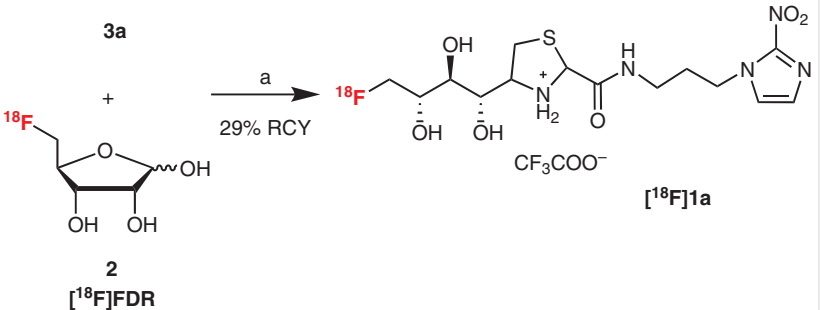

Scheme 6 Radiosynthesis of $\left[{ }^{18} \mathrm{~F}\right] 1 \mathrm{1a}$. Reagents and conditions: (a) $6 \mathrm{M}$ acetate buffer, pH 4.5, r.t., 30 min.

Eventually, we found that the use of a $6 \mathrm{M}$ acetate buffer solution $(70 \% \mathrm{v} / \mathrm{v}$ concentration) in the reaction mixture containing $\left[{ }^{18} \mathrm{~F}\right] \mathrm{FDR}(\mathbf{2}), \mathbf{3 a}$ and DTT (1:1) (in the range $2-4$ $\mathrm{M})$ at $\mathrm{pH} 4.5$, provided the highest RCY $(29.2 \%$, decay corrected). No further improvements could be achieved by changing buffer concentration, $\mathrm{pH}$ or extending further the reaction time.

The tracer identity was confirmed by superimposition of the UV-HPLC profile of the cold reference $\left[{ }^{19} \mathrm{~F}\right] \mathbf{1}$ a with the semi-preparative RP-HPLC radio-chromatogram of $\left[{ }^{18} \mathrm{~F}\right] \mathbf{1 a}$, acquired before purification of the radiotracer (Figure 2).

In conclusion, we have designed and synthesised the first candidate PET tracers (1) for hypoxia imaging based on the use of $\left[{ }^{18} \mathrm{~F}\right]$ FDR 2 as radiolabelling agent. The synthesis is based on the formation of a thiazolidine-ring-linkage between $\left[{ }^{18} \mathrm{~F}\right]$ FDR 2 and 1,2-thiol-amines 3, which occurs with moderate to good efficiency depending on the structure of spacer and linker featured in $\mathbf{3}$. The method was successfully tested for the radiosynthesis of $\left[{ }^{18} \mathrm{~F}\right] \mathbf{1 a}$, which was produced in $29.2 \%$ radiochemical yield and successfully purified by RP-HPLC. 


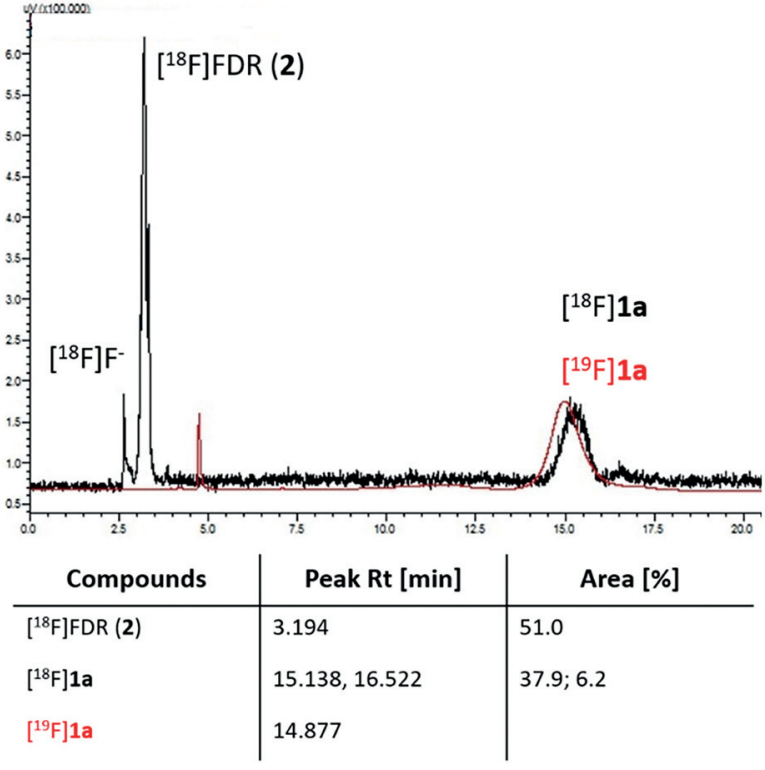

Figure 2 In black: semi-prep RP-HPLC Radio-analysis of radiotracer $\left[{ }^{18} \mathrm{~F}\right] 1 \mathrm{a}$ formation using $70 \% \mathrm{v} / \mathrm{v}$ of a $6 \mathrm{M}$ acetate buffer solution in the aqueous solution of $\left[{ }^{18} \mathrm{~F}\right] \mathrm{FDR}(\mathbf{2})$. In red: superimposed UV chromatogram of the cold reference $\left[{ }^{19} \mathrm{~F}\right] \mathbf{1}$ a obtained using the same RP-HPLC conditions.

\section{Funding Information}

M.M. gratefully acknowledges SULSA (http://www.sulsa.ac.uk/) for a PhD studentship

\section{Acknowledgment}

Mr Federico Toson is gratefully acknowledged for conducting preliminary experiments.

\section{Supporting Information}

Supporting information for this article is available online at https://doi.org/10.1055/s-0036-1591863.

\section{References and Notes}

(1) Brown, J. M.; Wilson, W. R. Nat. Rev. Cancer 2004, 4, 437.

(2) Höckel, M.; Vaupel, P. JNCI J. Natl. Cancer Inst. 2001, 93, 266.

(3) Ke, Q.; Costa, M. Mol. Pharmacol. 2006, 70, 1469.

(4) Muz, B.; de la Puente, P.; Azab, F.; Azab, A. K. Hypoxia 2015, 83.

(5) Harada, H. J. Radiat. Res. (Tokyo) 2011, 52, 545.

(6) Padhani, A. R.; Krohn, K. A.; Lewis, J. S.; Alber, M. Eur. Radiol. 2007, 17, 861 .

(7) Wigerup, C.; Påhlman, S.; Bexell, D. Pharmacol. Ther. (Supplement C) 2016, 164, 152.

(8) Horsman, M. R.; Mortensen, L. S.; Petersen, J. B.; Busk, M.; Overgaard, J. Nat. Rev. Clin. Oncol. 2012, 9, 674.

(9) Carlin, S.; Humm, J. L. J. Nucl. Med. 2012, 53, 1171.
(10) Lopci, E.; Grassi, I.; Chiti, A.; Nanni, C.; Cicoria, G.; Toschi, L.; Fonti, C.; Lodi, F.; Mattioli, S.; Fanti, S. Am. J. Nucl. Med. Mol. Imaging 2014, 4, 365.

(11) Peeters, S. G. J. A.; Zegers, C. M. L.; Lieuwes, N. G.; van Elmpt, W.; Eriksson, J.; van Dongen, G. A. M. S.; Dubois, L.; Lambin, P. Int. J. Radiat. Oncol. 2015, 91, 351.

(12) Li, X.-G.; Dall'Angelo, S.; Schweiger, L. F.; Zanda, M.; O'Hagan, D. Chem. Commun. 2012, 48, 5247.

(13) Dall'Angelo, S.; Zhang, Q.; Fleming, I. N.; Piras, M.; Schweiger, L. F.; O'Hagan, D.; Zanda, M. Org. Biomol. Chem. 2013, 11, 4551.

(14) Keinänen, O.; Li, X.-G.; Chenna, N. K.; Lumen, D.; Ott, J.; Molthoff, C. F.; Sarparanta, M.; Helariutta, K.; Vuorinen, T.; Windhorst, A. D.; Airaksinen, A. J. ACS Med. Chem. Lett. 2015, 7, 62.

(15) Li, X.-G.; Helariutta, K.; Roivainen, A.; Jalkanen, S.; Knuuti, J.; Airaksinen, A. J. Nat. Protoc. 2013, 9, 138.

(16) Forget, D.; Boturyn, D.; Defrancq, E.; Lhomme, J.; Dumy, P. Chem. Eur. J. 2001, 7, 3976.

(17) Zhang, L.; Tam, J. P. Anal. Biochem. 1996, 233, 87.

(18) Liu, C.-F.; Tam, J. P. J. Am. Chem. Soc. 1994, 116, 4149.

(19) Duthaler, R. O.; Wyss, B. Eur. J. Org. Chem. 2011, 24, 7419.

(20) O'Connell, C. E.; Ackermann, K.; Rowell, C. A.; Garcia, A. M.; Lewis, M. D.; Schwartz, C. E. Bioorg. Med. Chem. Lett. 1999, 9, 2095.

(21) Synthesis of $4 \mathbf{b}$ : An aqueous $1 \mathrm{M} \mathrm{LiOH}$ solution $(1.64 \mathrm{~mL}, 1.64$ mmol) was added at r.t. to a solution of $\mathbf{1 1}(200 \mathrm{mg}, 0.66 \mathrm{mmol})$ in THF (1.7 mL). The reaction mixture was stirred for $18 \mathrm{~h}$ at r.t. and then neutralised with a $1 \mathrm{M}$ aq. $\mathrm{HCl}$ solution, then extracted with EtOAc $(3 \times 2 \mathrm{~mL})$, dried and concentrated under reduced pressure to give $4 \mathbf{b}(186 \mathrm{mg}, 97.4 \%)$ as an oil. ${ }^{1} \mathrm{H} \mathrm{NMR}\left(\mathrm{CDCl}_{3}\right.$, $400 \mathrm{MHz}): \delta=9.07$ (br, $1 \mathrm{H}), 4.35(\mathrm{br}, 1 \mathrm{H}), 3.12(\mathrm{dd}, J=11.9,5.9$ $\mathrm{Hz}, 1 \mathrm{H}), 2.58(\mathrm{~d}, J=11.9 \mathrm{~Hz}, 1 \mathrm{H}), 2.39-2.19(\mathrm{~m}, 2 \mathrm{H}), 2.12-1.93$ $(\mathrm{m}, 2 \mathrm{H}), 1.72(\mathrm{~s}, 6 \mathrm{H}), 1.45(\mathrm{~s}, 9 \mathrm{H}) .{ }^{13} \mathrm{C} \mathrm{NMR}\left(\mathrm{CDCl}_{3}, 100 \mathrm{MHz}\right): \delta$ $=178.9,152.7,80.7,69.6,63.7,51.2,32.3,31.3,29.6$ (2C), 28.4 (3C) MS (ESI): $\mathrm{m} / z$ calcd for $\mathrm{C}_{13} \mathrm{H}_{23} \mathrm{NO}_{4} \mathrm{~S}: 290.2[\mathrm{M}+\mathrm{H}]^{+}, 312.1$ [M+Na $]^{+}$; found: $290.2[\mathrm{M}+\mathrm{H}]^{+}, 312.1[\mathrm{M}+\mathrm{Na}]^{+}$

(22) Synthesis of 4c: Hydrazine monohydrate $(124 \mu \mathrm{L}, 2.52 \mathrm{mmol})$ was added to a solution of $\mathbf{1 3}$ ( $340 \mathrm{mg}, 0.84 \mathrm{mmol}$ ) in EtOH (5 $\mathrm{mL}$ ) and the reaction mixture was heated at reflux for $3 \mathrm{~h}$. After cooling to $0{ }^{\circ} \mathrm{C}$ the resulting white precipitate was filtered off and the filtrate was concentrated under reduced pressure. The residue was dissolved with $\mathrm{Et}_{2} \mathrm{O}(5 \mathrm{~mL})$ and the resulting white precipitate was filtered, then the filtrate was concentrated under reduced pressure to afford $\mathbf{4 c}$ ( $448 \mathrm{mg}, 98.4 \%$ ) as a yellow oil. ${ }^{1} \mathrm{H}$ NMR $\left(\mathrm{CDCl}_{3}, 400 \mathrm{MHz}\right): \delta=4.16(\mathrm{br}, 1 \mathrm{H}), 3.00(\mathrm{dd}, J=$ 11.6, $6.1 \mathrm{~Hz}, 1 \mathrm{H}), 2.65-2.54(\mathrm{~m}, 2 \mathrm{H}), 2.47(\mathrm{~d}, J=11.6 \mathrm{~Hz}, 1 \mathrm{H})$, $1.73-1.49(\mathrm{~m}, 4 \mathrm{H}), 1.60(\mathrm{~s}, 6 \mathrm{H}), 1.44-1.41(\mathrm{~m}, 2 \mathrm{H}), 1.33(\mathrm{~s}, 9$ H). ${ }^{13} \mathrm{C}$ NMR $\left(\mathrm{CDCl}_{3}, 100 \mathrm{MHz}\right): \delta=152.3,79.8,69.4,64.1,41.8$, 31.3, 30.9, 30.2, $29.6(2 \mathrm{C}), 28.4$ (3C). MS (ESI): $\mathrm{m} / z$ calcd for $\mathrm{C}_{13} \mathrm{H}_{26} \mathrm{~N}_{2} \mathrm{O}_{2} \mathrm{~S}: 275.1[\mathrm{M}+\mathrm{H}]^{+}, 297.2[\mathrm{M}+\mathrm{Na}]^{+} 303.2[\mathrm{M}+\mathrm{K}]^{+}$; found: $275.2[\mathrm{M}+\mathrm{H}]^{+}, 297.2[\mathrm{M}+\mathrm{Na}]^{+}, 303.1[\mathrm{M}+\mathrm{K}]^{+}$

(23) Böhmer, V.; Dozol, J.-F.; Grüttner, C.; Liger, K.; Matthews, S. E.; Rudershausen, S.; Saadioui, M.; Wang, P. Org. Biomol. Chem. 2004, 2, 2327.

(24) Hay, M. P.; Wilson, W. R.; Moselen, J. W.; Palmer, B. D.; Denny, W. A. J. Med. Chem. 1994, 37, 381.

(25) Ebran, J.-P.; Dendane, N.; Melnyk, O. Org. Lett. 2011, 13, 4336.

(26) Bejot, R.; Carroll, L.; Bhakoo, K.; Declerck, J.; Gouverneur, V. Bioorg. Med. Chem. 2012, 20, 324.

(27) A shorter synthesis of 14d has been reported, see: Joyard Y., Azzouz R., Bischoff L., Papamicaël C., Labar D., Bol A., Bol V., Vera P., Grégoire V., Levacher V., Bohn P.; Bioorg. Med. Chem.; 2013, 
21: 3680; and references therein. However, imidazolyl carbinol 24 was already being used in our labs for a related project, therefore it was used as an intermediate for $\mathbf{1 4 d}$

(28) Synthesis of 25a: DIPEA ( $156 \mu \mathrm{L}, 0.92 \mathrm{mmol}$ ) and HATU (350 $\mathrm{mg}, 0.92 \mathrm{mmol}$ ) were added to a solution of $4 \mathbf{a}(200 \mathrm{mg}, 0.77$ mmol) in anhydrous $\mathrm{CH}_{2} \mathrm{Cl}_{2}(10 \mathrm{~mL})$ at $0{ }^{\circ} \mathrm{C}$ and the mixture was allowed to react at r.t. for $1 \mathrm{~h}$. Then the amino derivative 14a (260 mg, $1.53 \mathrm{mmol}$ ) dissolved in $\mathrm{CH}_{2} \mathrm{Cl}_{2}(2 \mathrm{~mL}$ ) was added to the mixture. After $16 \mathrm{~h}$ under stirring, the mixture was washed with a $0.5 \mathrm{M}$ aq. $\mathrm{NaOH}$ solution $(3 \times 6 \mathrm{~mL})$ and then with a $0.1 \mathrm{M}$ aq. $\mathrm{HCl}$ solution $(3 \times 6 \mathrm{~mL})$, dried over $\mathrm{Na}_{2} \mathrm{SO}_{4}$ and concentrated under reduced pressure. The crude material was purified by flash chromatography (Hex/EtOAc, from 8:2 to 7:3) to afford 25a (229 mg, 72.3\%) as a yellow oil. ${ }^{1} \mathrm{H}$ NMR $\left(\mathrm{CDCl}_{3}, 400 \mathrm{MHz}\right.$, mixture of rotamers): $\delta=7.32(\mathrm{~s}, 1 \mathrm{H}), 7.08(\mathrm{~s}, 1 \mathrm{H}), 6.55(\mathrm{br}, 1$ H), $4.72(\mathrm{br}, 1 \mathrm{H}), 3.42-3.11(\mathrm{~m}, 4 \mathrm{H}), 1.82(\mathrm{~s}, 3 \mathrm{H}), 1.73(\mathrm{~s}, 3 \mathrm{H})$, $1.42(\mathrm{~s}, 9 \mathrm{H}) .{ }^{13} \mathrm{C} \mathrm{NMR}\left(\mathrm{CDCl}_{3}, 100 \mathrm{MHz}\right): \delta=171.7,153.3,144.7$, 128.4, 127.0, 81.8, 71.4, 67.5, 47.4, 36.0, 31.0, 29.3, 28.9, 28.4 (3C). MS (ESI): $m / z$ calcd for $\mathrm{C}_{17} \mathrm{H}_{27} \mathrm{~N}_{5} \mathrm{O}_{5} \mathrm{~S}: 436.2[\mathrm{M}+\mathrm{Na}]^{+}, 452.0$ $[\mathrm{M}+\mathrm{K}]^{+}$; found: $436.1[\mathrm{M}+\mathrm{Na}]^{+}, 452.0[\mathrm{M}+\mathrm{K}]^{+}$

(29) Synthesis of $25 \mathrm{f}$ : A solution of $4 \mathbf{c}(152 \mathrm{mg}, 0.56 \mathrm{mmol})$ in $\mathrm{CH}_{2} \mathrm{Cl}_{2}(2 \mathrm{~mL})$ was added dropwise to a solution of $\mathrm{CDI}(90 \mathrm{mg}$, $0.56 \mathrm{mmol})$ in anhydrous $\mathrm{CH}_{2} \mathrm{Cl}_{2}(3 \mathrm{~mL})$, at $0{ }^{\circ} \mathrm{C}$ under $\mathrm{N}_{2}$ atmosphere, then the mixture was allowed to react at r.t. for $1 \mathrm{~h}$. After $16 \mathrm{~h}$ under stirring, the mixture was added via syringe to a solution of 14a (226 mg, $1.33 \mathrm{mmol})$ in $\mathrm{CH}_{2} \mathrm{Cl}_{2}(3 \mathrm{~mL})$ under $\mathrm{N}_{2}$ atmosphere. After $16 \mathrm{~h}$ under stirring the mixture was concentrated under recued pressure. Purification by FC on silica gel (Hex/EtOAc, from 3:7 to 7:3) gave 25f (148 $\mathrm{mg}, 56.7 \%$ ) as a yellow oil. ${ }^{1} \mathrm{H} \mathrm{NMR}\left(\mathrm{CDCl}_{3}, 400 \mathrm{MHz}, 2\right.$ rotamers): $\delta=7.35$ (br, 1 H), 7.02 (br, $1 \mathrm{H}), 5.55$ (br, $2 \mathrm{H}), 4.40(\mathrm{t}, J=6.9 \mathrm{~Hz}, 2 \mathrm{H}), 4.19$ (br, $1 \mathrm{H}), 3.24-2.94(\mathrm{~m}, 5 \mathrm{H}), 2.49(\mathrm{~d}, J=11.8 \mathrm{~Hz}, 1 \mathrm{H}), 2.05-1.86(\mathrm{~m}$, $2 \mathrm{H}), 1.81-1.66(\mathrm{~m}, 2 \mathrm{H}), 1.63$ (s, $3 \mathrm{H}), 1.61(\mathrm{~s}, 3 \mathrm{H}), 1.48-1.26$ $(\mathrm{m}, 11 \mathrm{H}) .{ }^{13} \mathrm{C}$ NMR $\left(\mathrm{CDCl}_{3}, 100 \mathrm{MHz}, 2\right.$ rotamers): $\delta=159.0$, 152.7, 144.6, 128.2, 127.1, 80.3, 69.4, 64.0, 47.8, 39.8, 36.6, 31.6, 31.4, 30.6, 30.1, 29.6, 28.4 (3C), 27.3. MS (ESI): $m / z$ calcd for $\mathrm{C}_{20} \mathrm{H}_{34} \mathrm{~N}_{6} \mathrm{O}_{5} \mathrm{~S}: 471.2[\mathrm{M}+\mathrm{H}]^{+}, 493.2[\mathrm{M}+\mathrm{Na}]^{+}$; found: 471.2 $[\mathrm{M}+\mathrm{H}]^{+}, 493.2[\mathrm{M}+\mathrm{Na}]^{+}$

(30) Synthesis of 3a: Compound 25a was dissolved in a TFA $/ \mathrm{H}_{2} \mathrm{O} / \mathrm{MeOH}$ 3:2:1 mixture and heated to $65^{\circ} \mathrm{C}$ for $2 \mathrm{~h}$. Solvents were then concentrated under reduced pressure at $60^{\circ} \mathrm{C}$, then the residue was dissolved in ethanol and passed through a SiliaBond ${ }^{\circledR}$ carbonate pad to give the crude $3 \mathbf{a}$ as trifluoroacetate salt (55.7 mg, 74.8\%). The compound was used in the next reaction without any further purification. ${ }^{1} \mathrm{H}$ NMR $\left(\mathrm{CD}_{3} \mathrm{OD}, 400\right.$ $\mathrm{MHz}$, in mixture with the dimer): $\delta=7.62-7.54(\mathrm{~m}, 1 \mathrm{H}), 7.20-$ $7.15(\mathrm{~m}, 1 \mathrm{H}), 4.60-4.42(\mathrm{~m}, 2 \mathrm{H}), 4.31-4.19(\mathrm{~m}, 1 \mathrm{H}), 3.52-3.33$ (m, $2 \mathrm{H}), 3.24-3.09(\mathrm{~m}, 2 \mathrm{H}), 2.19-2.00(\mathrm{~m}, 2 \mathrm{H}) .{ }^{13} \mathrm{C}$ NMR $\left(\mathrm{CD}_{3} \mathrm{OD}, 100 \mathrm{MHz}\right.$, in mixture with the dimer): $\delta=167.4,144.6$, 127.4, 127.2, 51.7, 47.4, 37.8, 36.3, 29.7. MS (ESI): $m / z$ calcd for $\mathrm{C}_{9} \mathrm{H}_{15} \mathrm{~N}_{5} \mathrm{O}_{3} \mathrm{~S}: 274.1[\mathrm{M}+\mathrm{H}]^{+}, 296.1[\mathrm{M}+\mathrm{Na}]^{+}$; found: $274.0[\mathrm{M}+\mathrm{H}]^{+}$, $296.0[\mathrm{M}+\mathrm{Na}]^{+}$

(31) Synthesis of 1a: $\left[{ }^{19} \mathrm{~F}\right] \mathrm{FDR}\left(\left[{ }^{19} \mathrm{~F}\right] 2\right)(5 \mathrm{mg}, 0.033 \mathrm{mmol})$ was added to a solution of $3 \mathbf{a}(32.0 \mathrm{mg}, 0.083 \mathrm{mmol})$ and DTT $(12.8$ $\mathrm{mg}, 0.083 \mathrm{mmol}$ ) in a $1 \mathrm{M}$ sodium acetate buffer solution $(\mathrm{pH}$ 4.5), then the mixture was allowed to react at $30^{\circ} \mathrm{C}$ for $20 \mathrm{~min}$. Purification by RP-HPLC (Column: Phenomenex Luna C18 $250 \times$ $10.00 \mathrm{~mm}, 5 \mu \mathrm{m}$; mobile phase: $\mathrm{A}\left(\mathrm{H}_{2} \mathrm{O}+0.05 \% \mathrm{TFA}\right), \mathrm{B}(\mathrm{ACN}+$ $0.05 \% \mathrm{TFA}$ ); gradient: from $5 \% \mathrm{~B}$ to $6 \% \mathrm{~B}$ in $15 \mathrm{~min}$; flow: $5 \mathrm{~mL}$ $\left.\min ^{-1} ; t_{R}: 12.5 \mathrm{~min}\right)$ gave $1 \mathrm{a}$ as trifluoroacetate salt $(10.6 \mathrm{mg}$, $61.3 \%$ ). NMR analyses were performed after treatment of $\mathbf{1 a}$ with SiliaBond ${ }^{\circledR}$ carbonate $(10 \% \mathrm{w} / \mathrm{w})$ in $\mathrm{EtOH}$, under gentle stirring for $1 \mathrm{~h}$ in order to freebase trifluoroacetate salt. ${ }^{1} \mathrm{H}$ NMR $\left(\mathrm{CD}_{3} \mathrm{OD}, 400 \mathrm{MHz}\right.$, - four diastereoisomers - two major isomer in $\sim 3: 2$ ratio were identified): $\delta=7.55(\mathrm{~d}, J=1.2 \mathrm{~Hz}, 1 \mathrm{H}), 7.16$ $(\mathrm{d}, J=1.2 \mathrm{~Hz}, 1 \mathrm{H}), 4.89-4.83(\mathrm{~m}, 1 \mathrm{H}), 4.62-4.42(\mathrm{~m}, 4 \mathrm{H}), 4.25$ (dd, $J=7.0,6.8 \mathrm{~Hz}, 1 \mathrm{H}), 4.09-4.04(\mathrm{~m}, 1 \mathrm{H}), 3.91(\mathrm{dd}, J=7.4,4.6$ $\mathrm{Hz}, 1 \mathrm{H}), 3.66$ (dd, $J=7.4,5.8 \mathrm{~Hz}, 1 \mathrm{H}), 3.39-3.23(\mathrm{~m}, 3 \mathrm{H}), 3.02-$ $2.91(\mathrm{~m}, 1 \mathrm{H}), 2.16-2.05(\mathrm{~m}, 2 \mathrm{H}) ; \delta$ (second isomer $)=7.57(\mathrm{~d}$, $J=1.2 \mathrm{~Hz}, 1 \mathrm{H}), 7.17(\mathrm{~d}, J=1.2 \mathrm{~Hz}, 1 \mathrm{H}), 4.92(\mathrm{~d}, J=2.6 \mathrm{~Hz}, 1 \mathrm{H})$, $4.67(\mathrm{dd}, J=9.8,3.0 \mathrm{~Hz}, 1 \mathrm{H}), 4.63-4.42(\mathrm{~m}, 3 \mathrm{H}), 4.25$ (dd, $J=7.0$, $6.8 \mathrm{~Hz}, 1 \mathrm{H}), 4.04-3.95(\mathrm{~m}, 1 \mathrm{H}), 3.85-3.75(\mathrm{~m}, 2 \mathrm{H}), 3.39-3.14$ $(\mathrm{m}, 3 \mathrm{H}), 3.02-2.91(\mathrm{~m}, 1 \mathrm{H}), 2.16-2.05(\mathrm{~m}, 2 \mathrm{H}) .{ }^{13} \mathrm{C}$ NMR $\left(\mathrm{CD}_{3} \mathrm{OD}, 100 \mathrm{MHz}\right.$, - four diastereoisomers - two major isomers in $\sim 3: 2$ ratio were identified): $\delta$ (first isomer) $=172.5,144.7$, $127.2,127.1,84.1\left(\mathrm{~d}, J_{\mathrm{CF}}=167 \mathrm{~Hz}\right), 73.6\left(\mathrm{~d}, J_{\mathrm{CF}}=7 \mathrm{~Hz}\right), 72.3,72.1$, $71.8\left(\mathrm{~d}, J_{\mathrm{CF}}=18 \mathrm{~Hz}\right), 71.4,65.8,35.8,34.9,30.0 ; \delta$ (second isomer $)=172.4,144.7,127.2,127.1,84.3\left(\mathrm{~d}, J_{\mathrm{CF}}=167 \mathrm{~Hz}\right), 73.6$ $\left(\mathrm{d}, J_{\mathrm{CF}}=7 \mathrm{~Hz}\right), 72.3,72.0,71.9,71.9\left(\mathrm{~d}, J_{\mathrm{CF}}=18 \mathrm{~Hz}\right), 70.2,66.2$, 36.6, 34.9. 29.9. $\left.{ }^{19} \mathrm{~F} \mathrm{NMR} \mathrm{(376} \mathrm{MHz,} \mathrm{CD}_{3} \mathrm{OD}\right): \delta$ (first isomer) $=$ $-233.0(\mathrm{dt}, J=48.0,22.7 \mathrm{~Hz}) ; \delta$ (second isomer) $=-233.6\left(\mathrm{dt}, J_{1}=\right.$ $48.0 \mathrm{~Hz}, J_{2}=22.3 \mathrm{~Hz}$ ); MS (ESI): $m / z$ calcd for: $\mathrm{C}_{14} \mathrm{H}_{22} \mathrm{FN}_{5} \mathrm{O}_{6} \mathrm{~S}$ : $408.1[\mathrm{M}+\mathrm{H}]^{+}, 430.1[\mathrm{M}+\mathrm{Na}]^{+}$; found: $408.0[\mathrm{M}+\mathrm{H}]^{+}, 430.0$ $[\mathrm{M}+\mathrm{Na}]^{+}$

(32) Optimised radiosynthesis of $\left[{ }^{18} \mathbf{F}\right] 1 \mathbf{a}$ : A solution of sodium acetate buffer ( $6 \mathrm{M}, \mathrm{pH} 4.5)$ was added to a solution of $\mathbf{3 a}(2.5$ $\mathrm{mg}, 6.4 \mu \mathrm{mol})$, DTT $(1 \mathrm{mg}, 6.4 \mu \mathrm{mol})$ and $\left[{ }^{18} \mathrm{~F}\right] \mathrm{FDR}\left(\left[{ }^{18} \mathrm{~F}\right] 2\right)(2.5-$ $10 \mathrm{MBq})$ in $0.5-1.0 \mathrm{~mL}$ of $\mathrm{H}_{2} \mathrm{O}$ to form a $70 \% \mathrm{v} / \mathrm{v}$ sodium acetate buffer solution (final concentration $4.2 \mathrm{M}$ ). After $\sim 20 \mathrm{~min}$ the mixture was purified by RP-HPLC (Column: Phenomenex Luna C18 $250 \times 10.00 \mathrm{~mm}, 5 \mu \mathrm{m}$ ) to give $\left[{ }^{18} \mathrm{~F}\right] \mathbf{1 a}$ in $29 \% \mathrm{RCY}$ (decay corrected) 